\title{
Changing Lifeways in the Maloti-Drakensberg Mountains, Southern Africa: Towards a History of Innovation and Belief in the Late Second Millennium AD
}

\author{
Rachel King*, David Pearce ${ }^{\dagger}$, Adelphine Bonneau ${ }^{\dagger}$ and Lara Mallen ${ }^{\dagger}$
}

Despite their environmental and geo-political marginality, southern Africa's MalotiDrakensberg Mountains (Figure 1) have been a significant locus of cultural creativity over the last two millennia. The past few decades have witnessed a steadily growing number of excavations on either side of the uKhahlamba-Drakensberg Escarpment, enabling a view of trans-montane connections between hunter-gathering and farming communities beginning around 1800 BP (Mitchell 2009a, 2009b). Particularly in the highlands of modern-day Lesotho, finds of domestic fauna and worked metal in late first-millennium hunter-gatherer encampments attest to the incorporation of new technologies and social connections into lifeways that also emphasised foraging and fishing. Looking to the late second millennium $\mathrm{AD}$, these mountains continued as a hub of interaction, with rock art offering insight into how cohorts of cattle-and-horse raiders forged new identities (Blundell 2004; Challis 2012, 2014, 2016; Mallen 2008). With crop agriculture and apparatuses of the

\footnotetext{
* Institute of Archaeology, UCL, London, WC1H OPY, UK

+ Rock Art Research Institute, University of the Witwatersrand, ZA

Corresponding author: Rachel King (tcrnrki@ucl.ac.uk)
}

colonial state restricted to the lowlands until the 1880s, the upper reaches of the MalotiDrakensberg in the nineteenth century became an 'interior world' (King and Challis 2017) where mobile polities and those cast as 'criminals' by the state could retain a measure of autonomy.

In this long view of the last two millennia in the Maloti-Drakensberg, archaeological evidence tends to cluster at two points in the chronological sequence: the mid-to-late first millennium $A D$ when hunter-gatherer contact with agriculturists effloresces, and the nineteenth century when the mountains became a notorious 'nest of thieves and vagrants' (Theal 2002: V, 208). Our project 'Changing Hunter-Gatherer Lifeways' targets the missing middle period in the second millennium. The project seeks to establish a chronologically constrained understanding of how mobile montane lifeways changed amidst a series of relatively rapid transformations occurring within and around the Maloti-Drakensberg. These transformations include an increasing agriculturist presence in the lowlands and livestock grazing in the highlands, changing patterns of wild game movement (especially elephants), and the onset of the Little Ice Age (c. 1500-1800 AD). To achieve the chronological resolution and material detail needed to address these questions, we have considered a diverse range 


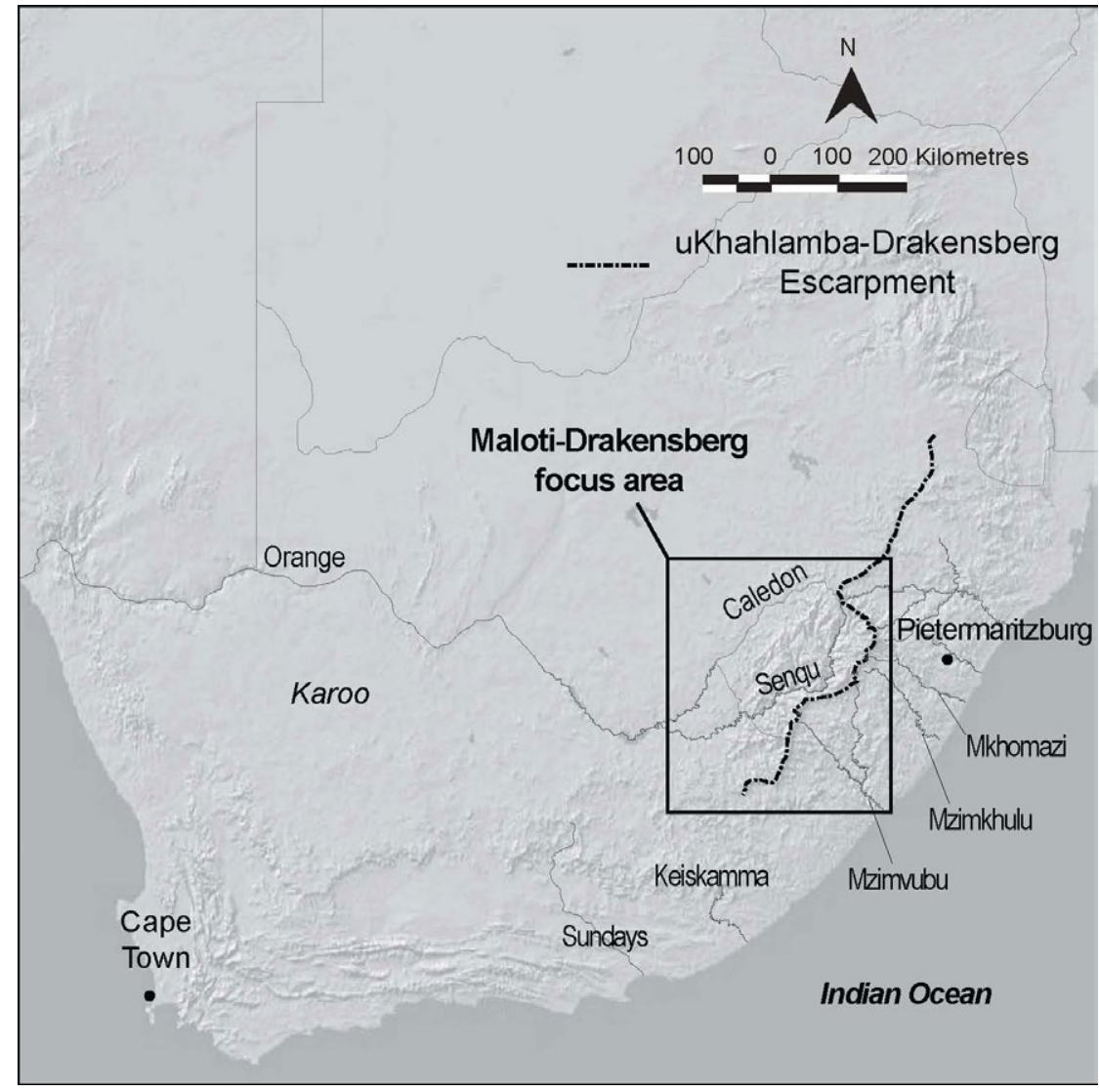

Figure 1: Map of southern Africa showing Maloti-Drakensberg study area. Map created using ArcGIS ${ }^{\circledR}$ software by Esri. ArcGIS ${ }^{\circledR}$ and ArcMap ${ }^{\mathrm{TM}}$ are the intellectual property of Esri and are used herein under license. Copyright (C) Esri. All rights reserved.

of archaeological evidence and site types: open air settlements (including stone-walled villages) and rock shelter encampments at multiple altitudes, rock art, and lithic and ceramic assemblages from new excavations and established collections. We aim to extend an earlier major programme of research that developed new techniques for directly dating and chemically characterising rock art pigments (Bonneau et al. 2011, 2014, 2017a, 2017b; Bonneau, Pearce and Higham 2016; Bonneau, Pearce and Pollard 2012; Hœrlé et al. 2016), specifically targeting images that can be linked to the second millennium $\mathrm{AD}$ (Figure 2).

Our project therefore builds on a growing body of research attesting to the significance of the Maloti-Drakensberg for understanding the dynamics of montane subsistence lifeways in sub-Saharan Africa, as well as continuing to develop cutting-edge analytical techniques. Further, we are endeavouring to build a picture of long-term history in the Maloti-Drakensberg that emphasises the creativity and contingency of how materials were created and used, and that takes a holistic view of the networks of knowledge and exchange at work by focusing on archaeology traditionally attributed to huntergatherers and agriculturists within the same research framework. Taking this approach enables us to address the nineteenth and twentieth century narratives that depict the Maloti-Drakensberg as an untamed and 


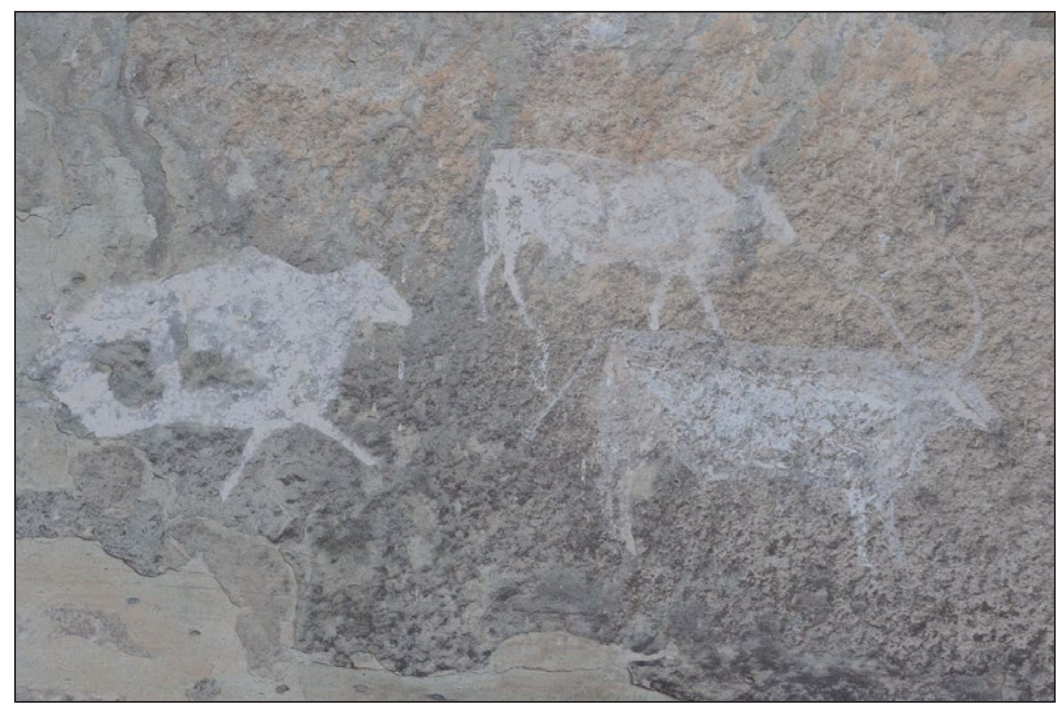

Figure 2: Paintings of cattle at the nearby FRE4 painted site. Five human figures painted in this shelter have been directly dated to 1297-present cal. BP (Bonneau et al. 2017a). Reproduced with permission.

untameable wilderness, and permit discussion of the rich cultural logics that prevailed in a place long treated as peripheral to the transformations that shaped southern Africa (King 2017).

\section{Mixed Methods, Mixed Spaces}

An enduring problem confronting southern African archaeology is tying the occupation of rock shelters to open-air sites and/or stone-walled settlements during the last millennium. This is due largely to preservation issues, few adequate provenance studies of lithic and ceramic raw materials, and a lack of sufficient chronological resolution tying the two spaces together. Our project aims to achieve this through radiometric dating and chemical characterisation of rock art pigments taken from rock shelters and excavation of stone-walled sites dating to within the last 500 years. This strategy represents a joining of two long-standing research projects in the Maloti-Drakensberg: one focusing on rock art pigment analysis, the other on characterising strategies for settlement and mobility in open-air sites. Beginning in 2016, this work has focused on a section of Maclear District, representing the southwestern edge of the Maloti-Drakensberg. Previous rock art pigment studies analysed 23 samples from six sites, giving a chronological range of $2998 \mathrm{cal}$. BP to the present (Bonneau et al. 2017a).

Archaeological survey of a farm within this district identified a cluster of abandoned stone-walled structures and associated middens (a site designated as 'Woodcliffs'), one of which was selected for excavation on the basis of pottery scattered on its surface (Figure 3).

Excavations demonstrated that while the upper strata of the midden had been eroded (replaced by colluvial sediments), the lower stratum remained in place and consisted almost entirely of ceramics deposited and fragmented in situ, along with a small number of beads and charcoal. Ceramic fragments were piece plotted and recovered for re-fitting, which is currently in progress but suggests at least three distinct and complete vessels were present, which include decorations and rim motifs. As the Maloti-Drakensberg Mountains have been believed to be relatively inhospitable 


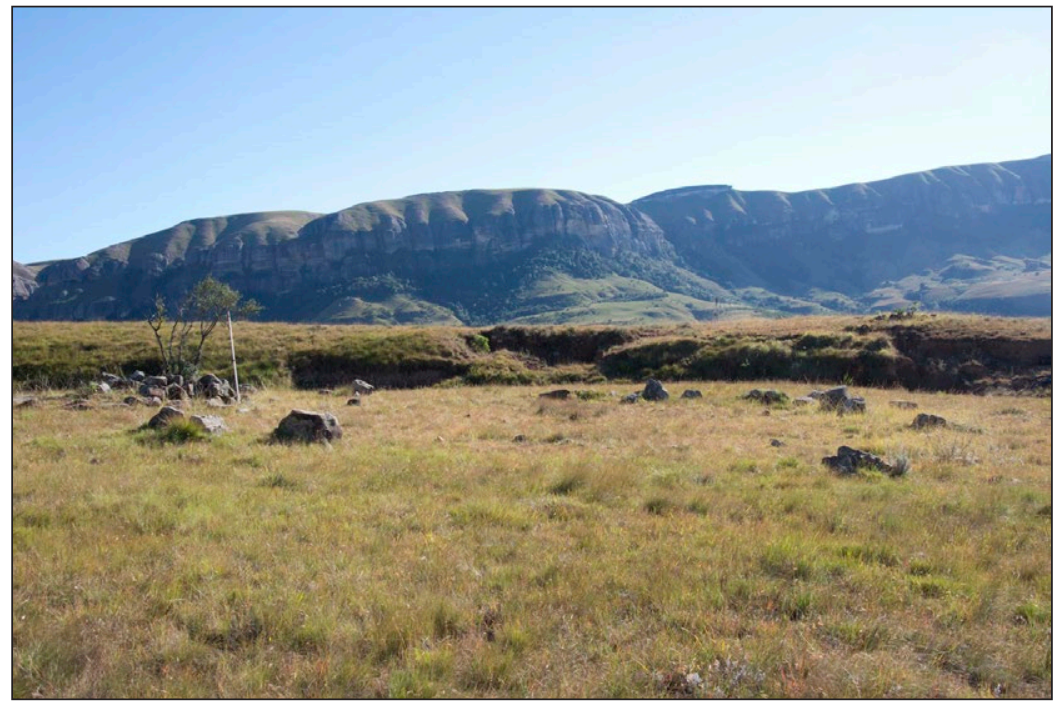

Figure 3: View over the Woodcliffs site showing its position on a spur overlooking a wide valley. Some stone walling is visible on the surface. Photo: D. Pearce.

to ceramic-producing agropastoralists until the nineteenth century, and primarily for those squeezed to the hinterlands by colonial encroachment, the archaeology of these communities has been relatively underexplored (King 2014). As such, our excavations represent one of the largest ceramic assemblages recovered from these mountains, and is certainly the most complete. Optically stimulated luminescence dating of ceramics is currently on-going, but excavated samples of seed beads (recovered using a 0.5 $\mathrm{mm}$ mesh) suggest that the ceramic-bearing layer was deposited after 1700 AD.

\section{Painting (and excavating) by Numbers}

Underpinning this project is the recognition that developing a picture of hunter-gathereragropastoralist interaction in the MalotiDrakensberg is a matter of assembling data points from a number of small sites rather than one or two large excavations. The archaeology of montane agropastoralists has been particularly elusive, perhaps because the climate and terrain inhibited settlement by people practicing cereal cultivation, but equally because the landscape encouraged an emphasis on livestock transhumance rather than the sorts of extensive crop agriculture available on the lower-lying plains. This project's finds thus far, combined with earlier excavations, dating programmes, and surveys, are steadily building a view of what economy and belief looked like in the Maloti-Drakensberg, and several themes have become clear which merit further investigation.

First, rock art was likely being executed very close to aggregated dwellings, opening the possibilities of connections between these dwellings and the painters themselves. While rock shelters containing rock art also show evidence of encampment, and painting may certainly have been a practice requiring privacy and specialist knowledge, at Woodcliffs we see it situated close to and possibly integrated within village life. Both painted subjects (cattle and shields, for instance) and dates (Bonneau et al. 2017a) clearly indicate that some paintings are late and relate to contact between groups. In southern Africa, painters' identities are often considered to be tied to subsistence. For example, fine-line painting traditionally is attributed to San hunter-gatherer style and finger-painted or geometric styles to farmers or herders, respectively. To the 
extent that we can say anything about the identities of the painters in our region, the location of painting amidst communities of people historically known to be practicing a range of subsistence lifeways - from hunting to herding to cattle rustling - suggests that we need to find other ways of thinking about identification.

Second, historians and archaeologists have long believed that the Maloti-Drakensberg did not support agropastoralist communities until the encroaching colonial frontier and homesteading strategies instituted by the British and Basotho governments encouraged settlers to move into higher altitudes (e.g. Mitchell 2009b, 2010; Vinnicombe 2009 [1976]; Wright 1971). Until then, the mountains were thought to have mainly hosted cohorts of cattle raiders or outlaws, or farming communities who may have temporarily withdrawn to higher ground to escape environmental hardship or political conflict (see King and Challis 2017 for details). Recent work illustrating that these sorts of 'refugia' could actually serve as more regular, stable homes (King 2017) has not shifted the conclusion that these mountains were inhospitable to aggregated village life - at least not without encouragement from a strong leader such as the Sotho chief Moshoeshoe I on the north-western side of the Escarpment. Woodcliffs falls outside of Moshoeshoe's ambit and indeed the ambit of any of the major regional chiefly powers, and forces us to consider that people in the last few centuries chose to settle in the southern mountains for reasons other than crisis or retreat. Further, we should also consider the livelihood strategies that may have supported Woodcliffs, which likely included a combination of seasonal transhumance, crop agriculture, and even cooperative relationships with hunter-gathering communities.

Finally, the ceramic assemblage at Woodcliffs represents one of the bestpreserved ever recovered from this region. Ceramic manufacturing technology and raw material provenance studies in southern Africa are not widespread, and have mostly clustered in the northern and western interior and eastern midlands (e.g. Bollong, Sampson and Smith, 1997; Fowler 2006, 2008; Fredriksen 2011; Rosenstein 2008;); this contrasts with more technological, chaîne opératoire focused ceramic studies prevalent in, for example, West Africa. Similarly, obtaining direct dates on ceramics has not been a widespread practice. Finds from Woodcliffs suggest that it is time these analytical practices arrived in the MalotiDrakensberg, where the lack of widespread interest in montane agropastoralists thus far has precluded any major ceramic study.

\section{Competing Interests}

The authors have no competing interests to declare.

\section{References}

Blundell, G 2004 Nqabayo's Nomansland: San rock art and the somatic past. Uppsala: Uppsala University.

Bollong, C A, Sampson, C G and Smith, A B 1997 Khoikhoi and Bushman pottery in the Cape Colony: Ethnohistory and Later Stone Age ceramics of the South African Interior. Journal of Anthropological Archaeology, 16(3): 269-299. DOI: https://doi.org/10.1006/jaar.1997.0311

Bonneau, A, Brock, F, Higham, T, Pearce, D G and Pollard, A M 2011 An improved pretreatment protocol for radiocarbon dating black pigments in San rock art. Radiocarbon, 53(3): 419-428. DOI: https://doi.org/10.1017/ S003382220003455X

Bonneau, A, Pearce, D G and Higham, T 2016 Establishing a chronology of San rock art using paint characterization and radiocarbon dating. In: Gutierrez, $\mathrm{M}$ and Honoré, E (eds) L'art rupestre d'Afrique, Actualité de la recherche, Actes du colloque International Paris, 15 au 17 Janvier 2014, Université Paris 1, Centre Panthéon et Musée du Quai Branly. Nanterre: Editions l'Harmattan. pp. 245-251.

Bonneau, A, Pearce, D G, Mitchell, P, Arthur, C, Higham, T, Lamothe, $M$ and 
Arsenault, D 2014 Comparing painting pigments and subjects: the case of white paints at the Metolong dam (Lesotho). In: Scott, R B, Braehmans, D, Carremans, M and Degryse, $\mathrm{P}$ (eds) Proceedings of the $39^{\text {th }}$ International Symposium on Archaeometry, Leuven, Belgium. Leuven: Centre for Archaeological Sciences. pp. 319-323.

Bonneau, A, Pearce, D G and Pollard, A M 2012 A Multi-technique characterization and provenance study of the pigments used in San rock art, South Africa. Journal of Archaeological Science, 39: 287-294. DOI: $\quad$ https://doi.org/10.1016/j. jas.2011.09.011

Bonneau, A, Pearce, D, Mitchell, P, Staff, R, Arthur, C, Mallen, L, Brock, F and Higham, T 2017a The earliest directly dated rock paintings from southern Africa: new AMS radiocarbon dates. Antiquity, 91: 322-333. DOI: https://doi. org/10.15184/aqy.2016.271

Bonneau, A, Staff, R, Higham, T, Brock, F, Pearce, D and Mitchell, P 2017b Successfully dating rock art in southern Africa using improved sampling methods and new characterization and pretreatment protocols. Radiocarbon, 59(3): 659-677. DOI: https://doi.org/10.1017/ RDC.2016.69

Challis, S 2012 Creolisation on the nineteenth-century frontiers of southern Africa: A case study of the AmaTola 'Bushmen' in the Maloti-Drakensberg. Journal of Southern African Studies, 38: 265-280. DOI: https://doi.org/10.1080/03057070 .2012 .666905

Challis, S 2014 Binding beliefs: The creolisation process in a 'Bushman' raider group in nineteenth-century southern Africa. In: Deacon, J and Skotnes, P (eds) The courage of Kabbo. Celebrating the 100th anniversary of the publication of 'Specimens of Bushman folklore'. Cape Town: UCT Press. pp. 247-265.

Challis, S 2016 Re-tribe and resist: The ethnogenesis of a creolised raiding band in response to colonialism. In Hamilton, $\mathrm{C}$ and Leibhammer, $\mathrm{N}$ (eds) Tribing and untribing the archive. Critical enquiry into the traces of the Thukela-Mzimkhulu region from the Early Iron Age until c. 1910. Pietermaritzburg: UKZN Press. pp. 282-299.

Fowler, K D 2006 Classification and collapse: The ethnohistory of Zulu ceramic use. Southern African Humanities, 18(2): 93-117.

Fowler, K D 2008 Zulu pottery production in the Lower Thukela Basin, KwaZulu-Natal, South Africa. Southern African Humanities, 20(2): 477-511.

Fredriksen, P D 2011 When knowledges meet: Engagements with clay and soil in southern Africa. Journal of Social Archaeology, 11(3): 283-310. DOI: https://doi. org/10.1177/1469605311403852

Hœrlé, S, Pearce, D G, Bertrand, L, Sandt, C and Menu, M 2016 Imaging the layered fabric of paints from Nomansland rock art (South Africa). Archaeometry 58: 182-199. DOI: https://doi.org/10.1111/ arcm.12235

King, R 2014 Voluntary barbarians of the Maloti-Drakensberg: The BaPhuthi chiefdom, cattle raiding, and colonial rule in nineteenth-century southern Africa. Unpublished thesis (Dphil), University of Oxford.

King, R 2017 Living on edge: New perspectives on anxiety, refuge, and colonialism in southern Africa. Cambridge Archaeological Journal, 27(3): 533-551. DOI: https:// doi.org/10.1017/S0959774317000312

King, R and Challis, S 2017 The interior world' of the nineteenth-century Maloti-Drakensberg mountains. Journal of African History, 58(2): 213-237. DOI: $\quad$ https://doi.org/10.1017/ S0021853716000700

Mallen, L 2008 Rock art and identity in the north Eastern Cape Province. Unpublished thesis (MA), University of the Witwatersrand.

Mitchell, P 2009a Gathering together a history of the People of the eland: Towards an archaeology of Maloti-Drakensberg hunter gatherers. In: Mitchell, $\mathrm{P}$ and Smith, B 
(eds) The eland's people: New perspectives in the rock art of the Maloti-Drakensberg Bushmen. Essays in memory of Patricia Vinnicombe. Johannesburg: Witwatersrand University Press. pp. 99-136.

Mitchell, P 2009b Hunter-gatherers and farmers: Some implications of 1,800 years of interaction in the Maloti-Drakensberg region of southern Africa. Senri Ethnological Studies, 73: 15-46.

Mitchell, P 2010 Making history at Sehonghong: Soai and the last Bushman occupants of his shelter. Southern African Humanities, 22: 149-170.

Rosenstein, D D 2008 Sorting out ceramics: Correlating change in the technol- ogy of ceramic production with the chronology of 18th and early 19th century western BaTswana towns. Unpublished thesis (MSc), University of Cape Town.

Theal, G M 2002 Basutoland Records. Thabane, M. (ed.). Roma: Institute of Southern African Studies.

Vinnicombe, P 2009 [1976] People of the eland: Rock paintings of the Drakensberg Bushmen as a reflection of their life and thought, 2nd edition. Johannesburg: Wits University Press.

Wright, J B 1971 Bushman raiders of the Drakensberg, 1840-1870. Pietermaritzburg: University of Natal Press.

How to cite this article: King, R, Pearce, D, Bonneau, A and Mallen, L 2018 Changing Lifeways in the Maloti-Drakensberg Mountains, Southern Africa: Towards a History of Innovation and Belief in the Late Second Millennium AD. Archaeology International, 21 (1), pp. 82-88. DOl: https://doi.org/10.5334/ ai-384

Submitted: 11 July $2018 \quad$ Accepted: 01 October 2018 Published: 05 December 2018

Copyright: (c) 2018 The Author(s). This is an open-access article distributed under the terms of the Creative Commons Attribution 4.0 International License (CC-BY 4.0), which permits unrestricted use, distribution, and reproduction in any medium, provided the original author and source are credited. See http://creativecommons.org/licenses/by/4.0/. 